\title{
EFFECTS OF POWER-FREQUENCY MAGNETIC FIELDS ON BODY MASS IN RATS: A POOLED ANALYSIS
}

\section{$\operatorname{AUTHOR(S):~}$}

Nishimura, Tsutomu; Tada, Harue; Teramukai, Satoshi; Mohri, Kaneo; Fukushima, Masanori

\section{CITATION:}

Nishimura, Tsutomu ...[et al]. EFFECTS OF POWER-FREQUENCY MAGNETIC FIELDS ON BODY MASS IN RATS: A POOLED ANALYSIS. Progress In Electromagnetics Research Letters 2012, 29: 127-138

\section{ISSUE DATE:}

2012

URL:

http://hdl.handle.net/2433/154557

RIGHT:

c 2012 EMW Publishing. 


\title{
EFFECTS OF POWER-FREQUENCY MAGNETIC FIELDS
} ON BODY MASS IN RATS: A POOLED ANALYSIS

\section{T. Nishimura ${ }^{1,}$, H. Tada ${ }^{2}$, S. Teramukai ${ }^{2}$, K. Mohri ${ }^{3,4}$, and M. Fukushima ${ }^{1}$}

${ }^{1}$ Translational Research Informatics Center, Minatojima-minamimachi 1-5-4, Chuo-ku, Kobe 650-0047, Japan

${ }^{2}$ Translational Research Center, Graduate School of Medicine, Kyoto University, Shogoin Kawahara-cho 54, Sakyo-ku, Kyoto 606-8507, Japan

${ }^{3}$ Aichi Micro Intelligent Corporation, Wanowari 1, Arao-machi, Tokai, Aichi 476-8666, Japan

${ }^{4}$ Nagoya Industrial Sciences Research Institute, Yotsuya-dori 1-13, Chikusa-ku, Nagoya, Aichi 464-0819, Japan

\begin{abstract}
There is some evidence that exposure of various animals to a power-frequency magnetic field can cause increases in body mass. However, the precise nature of the relationship is not clear, particularly for long-term exposure. To clarify the relationship between long-term power-frequency magnetic field exposure (2 years) and animal body mass, we conducted a pooled analysis of data in two studies to examine the impact of power-frequency magnetic field exposure on body mass as compared with sham-exposed rats of both sexes. Relative body mass was the response variable, and the study duration (in weeks), magnetic flux density $(\mu \mathrm{T})$, and daily exposure time (hours/day) were the explanatory variables with adjustment for the study. We analyzed by sex. The $P$-value $(P)$ was defined as the probability of having observed our data (or more extreme data) when the null hypothesis was true. In multiple linear regression analyses of male and female rats, performed separately, we obtained estimates of the effect on relative body mass of study duration (coefficients 0.0225 and 0.0201 , respectively; both $P<0.0001$ ), magnetic flux density (coefficient 0.0002 for males, $P<0.0001$; coefficient -0.0002 for females, $P=0.0015$ ), and daily exposure time (coefficient 0.046 for
\end{abstract}

Received 13 October 2011, Accepted 4 January 2012, Scheduled 25 January 2012

* Corresponding author: Tsutomu Nishimura (t246ra@kuhp.kyoto-u.ac.jp). 
males, $P=0.0007$; coefficient -0.072 for females, $P<0.0001)$. Our pooled analysis has shown that there is a possible relationship between duration of exposure to power-frequency magnetic fields and body mass in rats.

\section{INTRODUCTION}

There is some evidence that exposure of various animals, including mice and cattle, to a power-frequency magnetic field can increase body mass relative to unexposed controls [1-4]. This is a potentially interesting finding because the strength of the Earth's magnetic fields varies depending on latitude, and has varied over evolutionary time. However, except in the study by Babbitt et al. [1], the durations of exposure to power-frequency magnetic field in these studies were short, ranging from 28 to 50 days, and so the results of these studies do not necessarily indicate how long-term exposure might affect body mass. A number of other reports in the literature describe the effects of long-term exposure ( $>2$ years) to power-frequency magnetic field on animals (rats and mice) with respect to carcinogenesis $[5,6]$, but these studies were not designed primarily to ascertain the effects of powerfrequency magnetic field on body mass and so there is only minimal discussion of this matter.

To arrive at a conclusion about whether long-term exposure to power-frequency magnetic field affects animal body mass, in the present study we performed a pooled analysis of data from these previous studies. To facilitate comparisons and ensure that variations in experimental method had a minimal effect on our analysis we selected only studies performed using similar protocols. For our pooled analysis we focused initially on high-quality animal studies conducted by the National Toxicology Program (NTP), which is made up of four charter agencies of the US Department of Health and Human Services. The NTP has conducted studies to assess the risks, especially with respect to carcinogenicity, of long-term exposure to power-frequency magnetic fields. The details of the NTP studies were as follows.

Boorman et al. [5] carried out a 2 year whole-body exposure study to evaluate the chronic toxicity and possible oncogenicity of a $60 \mathrm{~Hz}$ power-frequency magnetic field in rats. Groups of 100 male and 100 female F344/N rats were exposed continuously to a pure, linearly polarized, transient-free $60 \mathrm{~Hz}$ power-frequency magnetic field at flux densities of $0 \mu \mathrm{T}$ (sham control), $2 \mu \mathrm{T}$ (Group 1), $200 \mu \mathrm{T}$ (Group 2), or $1000 \mu \mathrm{T}$ (Group 3). An additional group of 100 male and 100 female rats received intermittent $(1 \mathrm{~h} \mathrm{on} / 1 \mathrm{~h}$ off $)$ exposure to a powerfrequency magnetic field of $1000 \mu \mathrm{T}$ (Group 4). The average exposure 
was 9.25 or $18.5 \mathrm{~h} /$ day.

McCormick et al. [6] carried out a 2 year whole-body exposure study to evaluate the chronic toxicity and possible oncogenicity of a $60 \mathrm{~Hz}$ power-frequency magnetic field in mice. Groups of 100 male and 100 female $\mathrm{B}_{6 \mathrm{C}} 3 \mathrm{~F}_{1}$ mice were exposed to a pure, linearly polarized, transient-free $60 \mathrm{~Hz}$ power-frequency magnetic field at flux densities of $0 \mu \mathrm{T}$ (sham control), $2 \mu \mathrm{T}$ (Group 1), $200 \mu \mathrm{T}$ (Group 2), or $1000 \mu \mathrm{T}$ (Group 3). An additional group of 100 male and 100 female B6C3F 1 mice received intermittent $(1 \mathrm{~h}$ on $/ 1 \mathrm{~h}$ off $)$ exposure to a $1000 \mu \mathrm{T}$ power-frequency magnetic field (Group 4). The average exposure was 9.25 or $18.5 \mathrm{~h} /$ day.

In addition, Kullberg et al. [7] suggest that birds respond to a changing magnetic field by increasing their fat deposition. Therefore, we also researched the relationship between food consumption and exposure to a power-frequency magnetic field.

\section{MATERIALS AND METHODS}

\subsection{Search Strategy and Inclusion Criteria}

We identified trials conducted according to the methods of the NTP by searching the PubMed database (January 1990-July 2010). The search terms used were 'carcinogenicity' and 'electromagnetic field,' and the search was restricted to papers in English and Japanese that described animal studies. The titles and abstracts of the articles identified using this process were scanned to exclude any trials that were clearly irrelevant. The full text of the remaining articles was read to determine whether they contained information on the topic of interest. The reference lists of the selected articles were reviewed for additional pertinent articles.

In our analyses we included only studies that were conducted by the NTP or according to the study methods of the program, that had run for more than 2 years and in which animals exposed to a powerfrequency magnetic field and sham-exposed control animals were all dealt with in the same way and at the same time. We did not assess the quality of the methods used in the primary studies as we presumed that studies conducted by the NTP or according to its methods were of high quality. The following data were collected for each article: publication data (first author's last name, year of publication, country in which the study was performed); study design; number of animals; animal characteristics (animals, sex, age); interventions (magnetic flux density, duration of exposure, exposure hours/day); and body mass of animals and number of survivors at each assessment time point. Publication bias was not assessed because long-term studies conducted by the NTP 
or according to the methods of the NTP tend to be published whether the results are positive or negative.

\section{STATISTICAL ANALYSIS}

We conducted a regression analysis to examine the impact of powerfrequency magnetic field exposure on relative body mass (percentage of control body mass). We defined relative body mass as $100 \times$ (the body mass of animals exposed to a power-frequency magnetic field divided by the body mass of control animals at the same assessment time point in the same study). Firstly, we conducted a simple regression analysis of each study. Relative body mass was the response variable and the duration of study (in weeks) was the explanatory variable. Secondly, we conducted a multiple linear regression analysis by pooling the studies. Relative body mass was the response variable, and the duration of study (in weeks), magnetic flux density $(\mu T)$, daily exposure time (hours/day), and study (for adjustment) were the explanatory variables. In both analyses we analyzed by sex.

In addition, to investigate the relationship between food consumption and power-frequency magnetic field exposure we conducted a multiple linear regression analysis. We defined relative food consumption as $100 \times$ (the food consumption of animals exposed to a power-frequency magnetic field divided by the food consumption of control animals at the same assessment time point in the same study). Relative food consumption was the response variable and the duration of study (in weeks) and magnetic flux density were the explanatory variables. We analyzed by sex. We used a weighted regression model so that a larger number of survivors would have a greater influence on the results of the analysis. A $P$ value $(P)$ of 0.05 or less indicated statistical significance. The $P$ was defined as the probability of having observed our data (or more extreme data) when the null hypothesis was true. The cut-off level for statistical significance is usually taken to be 0.05 in the present study, as it is usually. Statistical analyses were performed using SAS version 9.2 (SAS Institute, Cary, NC, USA).

\section{RESULTS}

Our search of the PubMed database initially yielded 20 articles. However, 16 articles were excluded because they did not meet the criteria of running for more than 2 years or that animals exposed to a power-frequency magnetic field and sham-exposed control animals were dealt with in the same way and at the same time. Four potentially relevant articles were left. We read the full text of these four articles 
Table 1. Details of the studies included in our pooled analysis and the populations studied.

\begin{tabular}{|c|c|c|c|c|c|c|c|}
\hline $\begin{array}{l}\text { Study } \\
\text { no. }\end{array}$ & \multicolumn{2}{|c|}{ Papers } & Animal & $\begin{array}{l}\text { Average age of } \\
\text { animals when } \\
\text { study began }\end{array}$ & \multicolumn{2}{|c|}{$\begin{array}{c}\text { Duration } \\
\text { of exposure }\end{array}$} & $\begin{array}{c}\text { Frequency } \\
(\mathrm{Hz})\end{array}$ \\
\hline $\begin{array}{r}\mathrm{Ya} \\
\mathrm{T}\end{array}$ & $\begin{array}{l}\text { asui et al. } \\
\text { Takebe et }\end{array}$ & $\begin{array}{l}\text { [1997] and } \\
\text { al. [1999] }\end{array}$ & $\begin{array}{c}\text { F344 } \\
\text { rats }\end{array}$ & 5 weeks & & $\begin{array}{l}6 \text { h/day, } \\
4 \text { weeks }\end{array}$ & 50 \\
\hline $\begin{array}{r}\mathrm{Bc} \\
2 \text { and }\end{array}$ & $\begin{array}{l}\text { oorman e } \\
\text { National } \\
\text { Program }\end{array}$ & $\begin{array}{l}\text { t al. [1999] } \\
1 \text { Toxicology } \\
\text { [1999] }\end{array}$ & $\begin{array}{l}\mathrm{F} 344 / \mathrm{N} \\
\text { rats }\end{array}$ & $6-7$ weeks & $\begin{array}{r}18.5 \mathrm{o} \\
106\end{array}$ & $9.25 \mathrm{~h} / \mathrm{da}$ & 60 \\
\hline $\begin{array}{l}\text { Study } \\
\text { no. }\end{array}$ & Sex & $\begin{array}{l}\text { Sham } \\
\text { control }(0 \mu \mathrm{T})\end{array}$ & $\begin{array}{c}\text { Group } \\
1\end{array}$ & $\underset{2}{\text { Group }}$ & 3 & $\underset{4}{\text { Group }}$ & $\begin{array}{c}\text { Study } \\
\text { location }\end{array}$ \\
\hline 1 & $\begin{array}{l}\text { Male } \\
\text { Female }\end{array}$ & $\begin{array}{l}N=48 \\
N=48\end{array}$ & $\begin{array}{c}500 \mu \mathrm{T} \\
N=48 \\
N=48 \\
\end{array}$ & $\begin{array}{c}5000 \mu \mathrm{T} \\
N=48 \\
N=48\end{array}$ & & & $\begin{array}{l}\text { Ibaraki, } \\
\text { Japan }\end{array}$ \\
\hline 2 & $\begin{array}{c}\text { Male } \\
\text { Female }\end{array}$ & $\begin{array}{l}N=100 \\
N=100\end{array}$ & $\begin{array}{c}2 \mu \mathrm{T} \\
N=100 \\
N=100\end{array}$ & $\begin{array}{lr}200 \mu \mathrm{T} & 100 \\
N=100 & N= \\
N=100 & N=\end{array}$ & $\begin{aligned} & \mu \mu \mathrm{T} \\
= & 100 \\
= & 100\end{aligned}$ & $\begin{array}{c}1000 \mu \mathrm{T} \\
N=100 \\
N=100\end{array}$ & $\begin{array}{c}\text { Chicago, } \\
\text { USA }\end{array}$ \\
\hline
\end{tabular}

Table 2. Results of a simple linear regression analysis to investigate relative body mass with respect to study duration (weeks) in male and female rats.

\begin{tabular}{cccccc}
\hline Group & $\begin{array}{c}\text { No. of } \\
\text { data } \\
\text { points* }\end{array}$ & Coefficient & SE & $P$ value & $\begin{array}{c}\text { At } 90 \\
\text { weeks** }\end{array}$ \\
\hline $\begin{array}{c}\text { Male rats } \\
\text { (Yasui study) }\end{array}$ & 74 & 0.021 & 0.0017 & $<0.0001$ & 101.9 \\
\hline $\begin{array}{c}\text { Male rats } \\
\text { (Boorman study) }\end{array}$ & 128 & 0.016 & 0.0015 & $<0.0001$ & 101.4 \\
\hline $\begin{array}{l}\text { Female rats } \\
\text { (Yasui study) }\end{array}$ & 74 & 0.018 & 0.0024 & $<0.0001$ & 101.6 \\
\hline $\begin{array}{l}\text { Female rats } \\
\text { (Boorman study) }\end{array}$ & 128 & 0.023 & 0.0017 & $<0.0001$ & 102.1 \\
$\begin{array}{l}\text { Total number of assessment time points for power-frequency } \\
\text { exposure groups. }\end{array}$ & & & & \\
**As a percentage of control body mass. & & & \\
\hline
\end{tabular}


and checked the reference lists for other relevant articles. We thus identified four trials that were conducted by the NTP or according to the NTP's study methods $[5,6,8,9]$. We obtained detailed data on bodymass changes in three trials from a report [10] and book [11]. We excluded the study of Mandeville et al. [8] from the analysis because it did not show any detailed data. The general characteristics of the trials are described in Table 1. A total of 1288 rats and 1000 mice ( $50 \%$ female) were involved in these controlled trials: there were 992 rats and 800 mice in the groups exposed to a power-frequency magnetic field and 296 rats and 200 mice in the control groups.

The study of Yasui et al. [9] was a whole-body exposure study that was conducted to evaluate the effect of a $50 \mathrm{~Hz}$ power-frequency magnetic field on cancer rate in rats. In this study, male and female

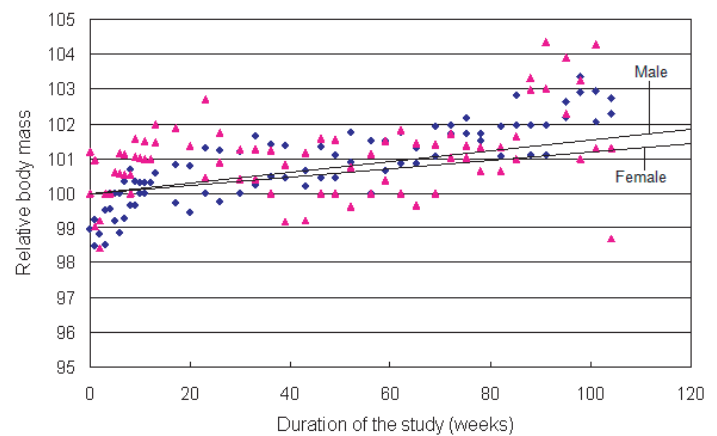

(a)

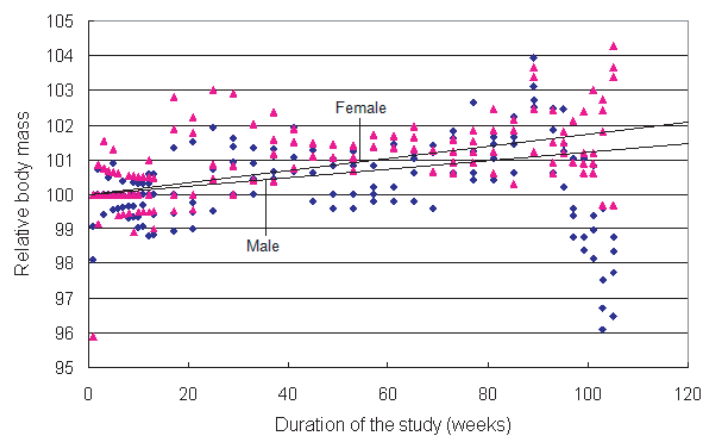

(b)

Figure 1. (a) Simple regression of the change in relative body mass with study duration in male and female rats (the results of Yasui etal., 1997). Squares indicate males and triangles indicate females. (b) Simple regression of the change in relative body mass with study duration in male and female rats (the results of Boorman et al., 1999). Squares indicate males and triangles indicate females. 
F344 rats, 48 per exposure group, were sham-exposed (sham control) or exposed to a power-frequency magnetic field of $500 \mu \mathrm{T}$ (Group 1) or $5000 \mu \mathrm{T}$ (Group 2) for 2 years. Animals were exposed from 5 to 109 weeks of age. The average exposure was $22.6 \mathrm{~h} /$ day.

Table 3. Results of a multiple linear regression analysis to investigate relative body mass with respect to study duration (weeks), magnetic flux density $(\mu \mathrm{T})$, and daily exposure time (hours) in male and female rats.

\begin{tabular}{|c|c|c|c|c|c|c|}
\hline Group & $\begin{array}{c}\text { No. of } \\
\text { trials }\end{array}$ & $\begin{array}{c}\text { No. of } \\
\text { data } \\
\text { points* }\end{array}$ & Covariate & Coefficient** & $\mathrm{SE}$ & $P$ value \\
\hline \multirow{3}{*}{$\begin{array}{l}\text { Male } \\
\text { rats }\end{array}$} & \multirow{3}{*}{2} & \multirow{3}{*}{202} & $\begin{array}{l}\text { Duration of } \\
\text { study } \\
\text { (relative body } \\
\text { mass/week) }\end{array}$ & 0.0225 & 0.0017 & $<0.0001$ \\
\hline & & & $\begin{array}{l}\text { Magnetic flux } \\
\text { density } \\
\text { (relative body } \\
\text { mass } / \mu \mathrm{T} \text { ) }\end{array}$ & 0.0002 & 0.00004 & $<0.0001$ \\
\hline & & & $\begin{array}{l}\text { Daily exposure } \\
\text { time } \\
\text { (relative body } \\
\text { mass/hour) }\end{array}$ & 0.046 & 0.013 & 0.0007 \\
\hline \multirow{3}{*}{$\begin{array}{c}\text { Female } \\
\text { rats }\end{array}$} & \multirow{3}{*}{2} & \multirow{3}{*}{202} & $\begin{array}{c}\text { Duration of } \\
\text { study } \\
\text { (relative body } \\
\text { mass/week) }\end{array}$ & 0.0201 & 0.0021 & $<0.0001$ \\
\hline & & & $\begin{array}{l}\text { Magnetic flux } \\
\text { density } \\
\text { (relative body } \\
\text { mass } / \mu \mathrm{T} \text { ) }\end{array}$ & -0.0002 & 0.00005 & 0.0015 \\
\hline & & & $\begin{array}{c}\text { Daily exposure } \\
\text { time } \\
\text { (relative body } \\
\text { mass/hour) }\end{array}$ & -0.072 & 0.017 & $<0.0001$ \\
\hline
\end{tabular}

\footnotetext{
* Total number of assessment time points for power-frequency magnetic field exposure groups.

**After adjustment for study.
} 
We conducted a regression analysis to examine the impact of exposure to a power-frequency magnetic field on relative body mass (percentage of control body mass), as described in the Statistical analysis section, above. We did not analyze mouse data because there was only one study using mice. We used data up to 90 weeks and did not use data after 90 weeks because animal mortality increased after that time.

In simple regression analyses of each study, we obtained estimates of the effect of relative body mass against study duration (male rats in the Yasui study, coefficient 0.021, Standard Error (SE) 0.0017, $P<0.0001$ ) (Fig. 1(a)); (male rats in the Boorman study, coefficient 0.016, SE 0.0015, $P<0.0001$ ) (Fig. 1(b)); (female rats in the Yasui study, coefficient 0.018, SE 0.0024, $P<0.0001$ )(Fig. 1(a)); (female rats in the Boorman study, coefficient 0.023, SE 0.0017, $P<0.0001$ ) (Fig. 1(b)). The results of the simple regression analyses are given in Table 2. The Standard Error (SE) is the standard deviation of the sampling distribution of a statistic.

In the multiple linear regression analysis of data for male rats we obtained estimates that were significantly different from zero for the regression of relative body mass against study duration (coefficient 0.0225 , SE $0.0017, P<0.0001$ ), magnetic flux density (coefficient 0.0002 , SE $0.00004, P<0.0001$ ), and against daily exposure time (coefficient 0.046, SE $=0.013, P=0.0007$ ) (see Table 3). In the multiple linear regression analysis of data for female rats we also

Table 4. Results of a multiple linear regression analysis to investigate relative food consumption with respect to study duration (weeks) and magnetic flux density $(\mu \mathrm{T})$ in male and female rats.

\begin{tabular}{cccccccc}
\hline Group & $\begin{array}{c}\text { No. of } \\
\text { trials }\end{array}$ & $\begin{array}{c}\text { No. of } \\
\text { data } \\
\text { points* }\end{array}$ & Covariate & Coefficient & SE & $P$ value \\
\hline $\begin{array}{c}\text { Male } \\
\text { rats }\end{array}$ & 1 & 36 & $\begin{array}{c}\text { Duration } \\
\text { of study } \\
\text { Magnetic } \\
\text { flux density }\end{array}$ & -0.0144 & 0.0086 & 0.10 \\
\hline $\begin{array}{c}\text { Female } \\
\text { rats }\end{array}$ & 1 & 36 & $\begin{array}{c}\text { Duration } \\
\text { of study } \\
\text { Magnetic } \\
\text { flux density }\end{array}$ & 0.00001 & 0.00341 & 0.0097 & 0.0016 \\
\hline
\end{tabular}

* Total number of assessment time points for power-frequency magnetic field exposure groups. 
obtained estimates that were significantly different from zero for the regression of relative body mass against study duration (coefficient 0.0201, SE 0.0021, $P<0.0001$ ), magnetic flux density (coefficient -0.0002 , SE $0.00005, P=0.0015$ ), and daily exposure time (coefficient $-0.072, \mathrm{SE}=0.017, P<0.0001$ ) (Table 3 ).

We obtained data on food consumption from the studies of Yasui et al. [11], whereas the other studies did not present data on food consumption. In multiple linear regression analyses of male rats and female rats, performed separately, we obtained estimates of the effect of study duration on relative food consumption (male rats: coefficient 0.0144 , SE 0.0086, $P=0.10$; female rats: coefficient -0.0331 , SE $0.0097, P=0.0016$ ) (Table 4) and of magnetic flux density on relative food consumption (male rats: coefficient -0.0001 , SE $0.0001, P=0.24$; female rats: coefficient 0.00005, SE 0.0001, $P=0.57$ ) (Table 4).

\section{DISCUSSION}

We reviewed the results of four studies in which animals exposed to a power-frequency magnetic field and animals that were sham-exposed were compared over a period of 2 years. Pooled analysis can detect small differences that may not be detected in each individual study because greater sample size gives more statistical power. In addition, we used different statistical methods from those used in the individual studies. A major limitation of this analysis was the small number of studies, because so few studies have been conducted that examine long-term effects and which show detailed data of animal body mass. However, a total of 1288 rats (50\% female) were involved in these controlled trials, and a pooled analysis of the kind presented here has not been performed until now. The mass-level phenomena and the increases in body mass seen in the studies analyzed could not be explained by any other conventional methodology. Therefore, this pooled analysis may give some insight into this field of biology.

In all groups, multiple linear regression analysis showed that duration of exposure to power-frequency magnetic fields was significantly positively correlated with body mass. In our multiple regression analysis there was a significant statistical relationship between study duration and food consumption in female rats, but the relationship showed a negative correlation. Therefore, food consumption may not affect gains in body mass. A dependence on magnetic flux density was shown in all groups analyzed (Table 3 ). In male rats, the relationship was a positive correlation, but in female rats the relationship was a negative correlation. This finding corresponds with evidence for sex differences in the effects of various types of 
magnetic field [12-17].

Our results agree with previous findings that short-term powerfrequency magnetic field exposure causes an increase in the body mass of mice and cattle [1-4,18]. Electrical fields alone did not produce any change in the body mass of pregnant lactating cows relative to unexposed controls [19], whereas magnetic fields did [2]. These results suggest that magnetic fields have an impact on body-mass gain in animals and correspond with our results.

Regarding the mechanism of body-mass gain, it is interesting that mild increases in plasma thyroid hormones (e.g., thyroxine) [20] and prolactin [21] have been found in pregnant lactating dairy cows that were exposed to a power-frequency magnetic field. Thyroxine is known to play key roles in growth, metabolism, reproduction, and somatic differentiation in developing and adult animals [22]. Also, in pregnant lactating dairy cows exposure to the electrical component of these fields alone $(10 \mathrm{kV} / \mathrm{m})$ did not affect production of prolactin [19]. It is possible that magnetic fields exert an effect on body size via plasma thyroxine and/or prolactin.

Our results may be explained by confounding variables. In the power-frequency magnetic field groups lighter animals may have died from the effects of the power-frequency magnetic field, as reported previously, because slow-growing animals and animals with low body mass are generally more infirm than rapid-growing and heavy animals, Then, in the groups exposed to a power-frequency magnetic field the heavier animals could have survived and thus mean body mass would be higher than for control groups. However, this theory can be rejected on the grounds that survival rates did not differ between exposure and control groups in any study.

In conclusion, our pooled analysis has shown that there is a possible relationship between duration of exposure to power-frequency magnetic fields and body mass in rats.

\section{REFERENCES}

1. Babbitt, J. T., A. I. Kharazi, J. M. G. Taylor, C. B. Bonds, D. Zhuang, et al., "Increased body weight in C57BL/6 female mice after exposure to ionizing radiation or $60 \mathrm{~Hz}$ magnetic fields," International Journal of Radiation Biology, Vol. 77, 875-882, 2001.

2. Rodriguez, M., D. Petitclerc, D. H. Nguyen, E. Block, and J. F. Burchard, "Effect of electric and magnetic fields $(60 \mathrm{~Hz})$ on production, and levels of growth hormone and insulin-like growth 
factor 1, in lactating, pregnant cows subjected to short days," Journal of Dairy Science, Vol. 85, 2843-2849, 2002.

3. Burchard, J. F., D. H. Nguyen, and H. G. Monardes, "Exposure of pregnant dairy heifer to magnetic fields at $60 \mathrm{~Hz}$ and $30 \mu \mathrm{T}$," Bioelectromagnetics, Vol. 28, 471-476, 2007.

4. Gerardi, G., A. De Ninno, M. Prosdocimi, V. Ferrari, F. Barbaro, et al., "Effects of electromagnetic fields of low frequency and low intensity on rat metabolism," Biomagn. Res. Technol., Vol. 6, 3, 2008.

5. Boorman, G. A., D. L. McCormick, J. C. Findlay, J. R. Hailey, J. R. Gauger, et al., "Chronic toxicity/oncogenicity evaluation of $60 \mathrm{~Hz}$ (power frequency) magnetic fields in F344/N rats," Toxicol. Pathol., Vol. 27, 267-278, 1999.

6. McCormick, D. L., G. A. Boorman, J. C. Findlay, J. R. Hailey, T. R. Johnson, et al., "Chronic toxicity/oncogenicity evaluation of $60 \mathrm{~Hz}$ (power frequency) magnetic fields in B6C3F1 mice," Toxicol. Pathol., Vol. 27, 279-285, 1999.

7. Kullberg, C., J. Lind, T. Fransson, S. Jakobsson, and A. Vallin, "Magnetic cues and time of season affect fuel deposition in migratory thrush nightingales (luscinia luscinia)," Proceedings of the Royal Society of London Series B, Vol. 270, 373-378, 2003.

8. Mandeville, R., E. Franco, S. Sidrac-Ghali, L. Paris-Nadon, N. Rocheleau, et al., "Evaluation of the potential carcinogenicity of $60 \mathrm{~Hz}$ linear sinusoidal continuous-wave magnetic fields in fischer F344 rats," FASEB J., Vol. 11, 1127-1136, 1997.

9. Yasui, M., T. Kikuchi, M. Ogawa, Y. Otaka, M. Tsuchitani, et al., "Carcinogenicity test of $50 \mathrm{~Hz}$ sinusoidal magnetic fields in rats," Bioelectromagnetics, Vol. 18, 531-540, 1997.

10. "NTP toxicology and carcinogenesis studies of 60-HZ magnetic fields IN F344/N rats and B6C3F1 mice (whole-body exposure studies)," Natl. Toxicol. Program Tech. Rep. Ser., Vol. 488, 1$168,1999$.

11. Takebe, H, T. Shiga, M. Kato, and E. Masada, Health Effects of Electromagnetic Field, Bunkodo, Tokyo, 1999, in Japanese.

12. Kavaliers, M., K. P. Ossenkopp, F. S. Prato, D. G. L. Innes, L. A. M. Galea, et al., "Spatial learning in deer mice: Sex differences and the effects of endogenous opioids and $60 \mathrm{~Hz}$ magnetic fields," Journal of Comparative Physiology A Sensory Neural and Behavioral Physiology, Vol. 179, 715-724, 1996.

13. Mulligan, S. and M. A. Persinger, "Perinatal exposures to rotating magnetic fields 'demasculinize' neuronal density in the medial 
preoptic nucleus of male rats," Neurosci. Lett., Vol. 253, 29-32, 1998.

14. Choleris, E., A. W. Thomas, K. P. Ossenkopp, M. Kavaliers, P. Valsecchi, et al., "Sex differences in conditioned taste aversion and in the effects of exposure to a specific pulsed magnetic field in deer mice peromyscus maniculatus," Physiology \& Behavior, Vol. 71, 237-249, 2000.

15. Jiang, M. L., T. Z. Han, W. Pang, and L. Li, "Gender- and agespecific impairment of rat performance in the Morris water maze following prenatal exposure to an MRI magnetic field," Brain Res., Vol. 995, 140-144, 2004.

16. Mitsutake, G., K. Otsuka, M. Hayakawa, M. Sekiguchi, G. Cornelissen, et al., "Does Schumann resonance affect our blood pressure?" Biomed. and Pharmacother., Vol. 59, Suppl 1, S10-14, 2005.

17. Cason, A. M., M. DenBleyker, K. Ferrence, J. C. Smith, and T. A. Houpt, "Sex and estrous cycle differences in the behavioral effects of high-strength static magnetic fields: role of ovarian steroids," American Journal of Physiology-Regulatory Integrative and Comparative Physiology, Vol. 290, R659-R667, 2006.

18. Svedenstal, B. M. and K. J. Johanson, "Effects of exposure to $50 \mathrm{~Hz}$ or $20 \mathrm{~Hz}$ magnetic fields on weights of body and some organs of CBA mice," In Vivo, Vol. 12, 293-298, 1998.

19. Burchard, J. F., D. H. Nguyen, H. G. Monardes, and D. Petitclerc, "Lack of effect of $10 \mathrm{kV} / \mathrm{m} \quad 60 \mathrm{~Hz}$ electric field exposure on pregnant dairy heifer hormones," Bioelectromagnetics, Vol. 25, 308-312, 2004.

20. Burchard, J. F., D. H. Nguyen, and M. Rodriguez, "Plasma concentrations of thyroxine in dairy cows exposed to $60 \mathrm{~Hz}$ electric and magnetic fields," Bioelectromagnetics, Vol. 27, 553-559, 2006.

21. Rodriguez, M., D. Petitclerc, J. F. Burchard, D. H. Nguyen, and E. Block, "Blood melatonin and prolactin concentrations in dairy cows exposed to $60 \mathrm{~Hz}$ electric and magnetic fields during $8 \mathrm{~h}$ photoperiods," Bioelectromagnetics, Vol. 25, 508-515, 2004.

22. Lin, J. C., "High-tension transmission-line exposure of pregnant dairy heifers," IEEE Antennas and Propagation Magazine, Vol. 49, 202-204, 2007. 